\title{
ПРИКЛАДНОЙ АНАЛИЗ
}

\author{
APPLIED ANALYSIS
}

Научная статья / Research article

\section{Ключевые модели взаимодействия религиозных институтов в контексте государственно-церковных отношений на примере России и Египта}

\author{
Г.О. Лукьянова $\mathbb{Q}$, О.С. Чикризова $\square$ \\ Российский университет дружбы народов, Москва, Российская Федерация \\ $\triangle$ chikrizova-os@rudn.ru
}

\begin{abstract}
Аннотация. Статья посвящена выявлению и сравнительному анализу особенностей государственноцерковных отношений в России и Египте. В настоящее время наблюдается заметное повышение роли религии и религиозных институтов в мировой политике, а также переосмысление процесса секуляризации общественной жизни. Религия по-прежнему нередко становится причиной дискриминации, гонений на отдельные группы общества; не снижается «градус» исламофобии в странах Запада и религиофобии - в мире. В этих условиях также возрастает значимость государственно-церковных отношений внутри ключевых международных акторов. Цель исследования заключается в сравнительном анализе особенностей государственной политики России и Египта в отношении религии, чтобы разработать рекомендации по использованию российских религиозных институтов по укреплению позиций России на Ближнем Востоке. Россия и Египет выбраны в качестве объектов исследования, поскольку эти страны имеют богатую историю взаимодействия в религиозной сфере, которая станет базисом для сотрудничества религиозных институтов двух стран. Кроме того, Египет - одно из ключевых государств Ближнего Востока, где российское влияние никогда не было доминирующим, но именно там религиозные организации типа Русской православной церкви (РПЦ) наиболее активно и успешно проводили интересы России. Методологически статья опирается на исторический и эмпирический институционализм, а также сравнительный анализ и историко-генетический метод. Новизна исследования состоит в том, что разработаны четыре модели взаимодействия религиозных общин, которые построены на двух критериях, таких как: а) наличие религиозных институтов, представляющих интересы той или иной общины; б) статус религии в государстве (доминирующая или религия меньшинства). Практическая значимость исследования состоит в том, что на основе выделенных особенностей государственно-церковных отношений в Египте предложены рекомендации по совершенствованию использования религиозных организаций России для продвижения государственных интересов в Египте.

Ключевые слова: Россия, Египет, государственно-церковные отношения, государственная политика в отношении религии, Русская православная церковь, РПЦ
\end{abstract}

Благодарности: Исследование выполнено при финансовой поддержке РФФИ в рамках научного проекта № 20-014-41002 «Взаимодействие России и Русской православной церкви с мусульманскими и христианскими общинами на Ближнем Востоке».

(C) Лукьянова Г.О., Чикризова О.С., 2021

This work is licensed under a Creative Commons Attribution 4.0 International License.

https://creativecommons.org/licenses/by/4.0/ 
Для цитирования: Лукьянова Г.О., Чикризова О.С. Ключевые модели взаимодействия религиозных институтов в контексте государственно-церковных отношений на примере России и Египта // Вестник Российского университета дружбы народов. Серия: Международные отношения. 2021. T. 21. № 4. C. 712-733. DOI: 10.22363/2313-0660-2021-21-4-712-733

\title{
Key Models of Religious Institutions' Interaction in the Context of the State-Church Relations in Russia and Egypt
}

\author{
Galina O. Lukyanova ${ }^{\oplus}$, Olga S. Chikrizova $₫$ \\ Peoples' Friendship University of Russia (RUDN University), Moscow, Russian Federation \\ \chikrizova-os@rudn.ru
}

\begin{abstract}
The article reveals and comparatively analyses the peculiarities of the state-church relations in Russia and Egypt. Currently, the role of religion and religious institutions in world politics is actively increasing, as well as the process of secularization of public life is being redefined. Religion still often becomes the cause of discrimination, persecution of certain groups of society; the level of Islamophobia in Western countries and Religiophobia in the whole world is not decreasing. In these conditions, the importance of state-church relations within key international actors is also growing. The purpose of the study is to provide comparative analysis of the specifics of the state religion policy of Russia and Egypt in order to develop recommendations for the use of Russian religious institutions to strengthen Russia's position in the Middle East. Russia and Egypt were chosen as research objects, since these countries have a rich history of interaction in the religious sphere, which could become a basis for the future cooperation between religious institutions of the two countries. In addition, Egypt is one of the key states in the Middle East, where Russian influence has never been dominant, but where exactly religious organizations such as the Russian Orthodox Church (ROC) most actively and successfully pursued Russia's interests. Methodologically, the article is based on historical and empirical institutionalism, as well as comparative analysis and historical-genetic method. The study is quite novel, as it identifies four models of interaction between religious communities, which are based on two criteria: a) presence of religious institutions representing the interests of a particular community; b) status of religion in the state (dominant / minority religion). The practical significance of the study lies in its attempt to make recommendations for improving the use of religious organizations in Russia to promote state interests in Egypt on the basis of the highlighted features of state-church relations in Egypt.
\end{abstract}

Key words: Russia, Egypt, state-church relations, state religion policy, Russian Orthodox Church, ROC

Acknowledgements: The research was funded by RFBR according to the scientific project No. 20-014-41002 "Interaction between Russia and the Russian Orthodox Church with Muslim and Christian communities in the Middle East".

For citation: Lukyanova, G. O., \& Chikrizova, O. S. (2021). Key models of religious institutions' interaction in the context of the state-church relations in Russia and Egypt. Vestnik RUDN. International Relations, 21(4), 712-733. (In Russian). https://doi.org/10.22363/2313-0660-2021-21-4-712-733

\section{Введение}

В мае 2022 г. в Санкт-Петербурге состоится Всемирная конференция по межрелигиозному и межэтническому диалогу под эгидой $\mathrm{OOH}^{1}$, направленная на создание условий для взаимодействия глав государств, лидеров

\footnotetext{
${ }^{1}$ См.: Резолюция ГА ООН A/Res/72/278, принятая 22 мая 2018 г. https://undocs.org/pdf?symbol=ru/A/RES/ 72/278 (дата обращения: 13.07.2021); Всемирная межрелигиозная конференция пройдет в России в 2022 году // РИА Новости. 20.01.2021. https://ria.ru/20210120/ religii-1593800514.html (дата обращения: 13.07.2021).
}

ведущих религиозных сообществ и общественных деятелей по вопросам сохранения культурного, конфессионального и этнического разнообразия. Примечательно, что в 2022 г. исполнится 40 лет, с тех пор как в мае 1982 г. в Москве прошла Всемирная конференция религиозных деятелей, в которой участвовали «590 представителей буддистской, зороастрийской, индуистской, иудаистской, мусульманской, сикхской, синтоистской и христианской религий из 90 стран всех континентов» (Керимов, 1983, с. 162). 
Для России как полиэтнического и многоконфессионального государства, имеющего многовековую историю мирного сосуществования представителей многочисленных народностей и религий, конференция может стать возможностью закрепиться в качестве лидера международного сообщества по налаживанию диалога между политиками и религиозными деятелями с целью гуманизации международных отношений и мировой политики. Конференция позволит главам крупнейших религиозных общин мира донести до политических лидеров взгляды на решение глобальных проблем, урегулирование многочисленных конфликтов, а также преодоление распространения экстремизма, национализма и религиофобии.

В этой связи особенно актуальным представляется рассмотрение особенностей государственно-церковных отношений в Египте, который выступает одной из ведущих стран арабо-мусульманского мира и неотъемлемой частью Святой земли. Будучи также многоконфессиональным государством, Египет сталкивается с проблемами дискриминации по религиозному признаку. В то же время исторически Египет выступал центром суннитошиитского сближения в исламе: в Каире в 1947 г. молодым иранским муджтахидом Мухаммадом Таки аль-Кумми была основана ассоциация по сближению исламских течений «Джамаат ат-такриб», создание которой поддержали улемы Аль-Азхара и египетское правительство. Деятельность «Джамаат аттакриб» ознаменовала важный шаг в деле преодоления суннито-шиитских разногласий, хотя и не привела к их полному урегулированию: ассоциация пала жертвой кризиса 1960 г. в египетско-иранских отношениях (Чикризова, 2018, с. 169-170). Тем не менее Египет еще не раз обратится к идее возрождения «Джамаат ат-такриб» в стремлениях возглавить внутриисламский диалог.

В последние годы Египет в лице АльАзхара становится одним из главных локомотивов межрелигиозного диалога (Fahmi, 2019). Так, в феврале 2019 г. в Абу-Даби состоялась историческая встреча папы Римского Франциска и верховного имама АльАзхара д-ра Ахмада ат-Тайиба, которой в апреле 2017 г. предшествовало выступление папы Франциска с речью о межрелигиозном диалоге в египетском университете. По итогам встречи, на которой также присутствовали представители Русской православной церкви (РПЦ) $)^{2}$, подписана декларация «О человеческом братстве во имя мира и мирного сосуществования», призванная возобновить диалог между христианством и исламом в условиях, когда последователи обеих религий столкнулись с проявлениями религиофобии (религиозной нетерпимости) и даже физическим истреблением за религиозные убеждения, которым подвергаются как христиане, так и мусульмане со стороны джихадистских террористических группировок типа ИГИЛ ${ }^{3}$.

Важно отметить, что для России и Египта, имеющих богатейшую историю духовных связей, взаимодействие в религиозной сфере является естественным. В свою очередь, исторически во взаимоотношениях Российского государства со странами Арабского Востока религиозная миссия и дипломатия были неразрывны. При этом в задачи авторов статьи не входит анализ двусторонних российско-египетских отношений, которым посвящены многочисленные основательные труды ведущих российских исследователей, в частности А.3. Егорина (1998; 2016), В.В. Белякова (2007; 2010), Г.В. Горячкина (2014) и С.А. Кириллиной (2000), а также монография египетской исследовательницы М. Халиль (2019).

\section{Методология исследования}

Исследование опирается на исторический институционализм, который позволяет анализировать социальные институты в исторической динамике и учитывать, что они неравномерно представляют различные социальные группы и их интересы (Peters, 2000; Hall \& Taylor, 1996; Hurd, 2017), а также эмпирический институционализм, предусматривающий

\footnotetext{
2 Представители Русской Православной Церкви приняли участие во Всемирной конференции «Человеческое братство» // РПЦ. 08.02.2019. URL: http://www.patriarchia.ru/db/text/5370269.html (дата обращения: 15.07.2021).

${ }^{3}$ Организация запрещена в РФ.
} 
прямую взаимосвязь между институтами и политическим выбором и дающий возможность выявить специфику государственноцерковных отношений в конкретном государстве (Martino, 2014; Fox, 2015; 2019).

Используя базу данных проекта «Религия и государство» ${ }^{4}$, проводимого в Университете Бар-Илана (Рамат-Ган, Израиль) и сосредоточившего информацию о государственнорелигиозных отношениях в 183 странах мира за 1990-2014 гг., в том числе разработанные и рассчитанные в рамках проекта индексы, авторы дают характеристику религиозной ситуации в Египте, а также проводят сравнительный анализ государственно-церковных отношений в Египте и России.

Под государственно-церковными отношениями понимается «совокупность исторически складывающихся и изменяющихся форм взаимосвязей и взаимоотношений институтов государства, включая органы власти и управления, государственные учреждения и организации, с одной стороны, и религиозных объединений (религиозных организаций, религиозных групп, руководящих или координирующих органов, духовных образовательных учреждений), а также учреждений и предприятий религиозных организаций с другой. В основе этих отношений лежат законодательно закрепленные представления о месте религии и религиозных объединений в жизни общества, их функциях, сферах деятельности и компетенции всех субъектов данных отношений» (Шахов, 2013, с. 12).

Цель исследования заключается в определении наиболее эффективных механизмов и инструментов, которые может применить Россия во взаимодействии с мусульманскими и христианскими общинами Египта в рамках традиционной опоры для российской дипломатии в регионе Ближнего Востока - религиозных организаций (главным образом РПЦ), а также с учетом особенностей политики, проводимой Египтом как в отношении представителей доминирующей религии, так и религиозных меньшинств. Под доминирующей

${ }^{4}$ The Religion and State Project, Round $3 / /$ The ARDA. URL: https://www.thearda.com/Archive/Files/ Descriptions/RAS3.asp (accessed: 21.09.2021). религией понимается та религия, к которой относит себя большинство населения того или иного государства, при этом данная религия может как иметь статус государственной, так и не обладать подобным статусом в соответствии с национальным законодательством.

Структура статьи обусловлена методологией исследования. Первый раздел посвящен рассмотрению особенностей религиозной ситуации в современном Египте с целью выявления групп религиозных меньшинств и формированию понимания, представлены ли они какими-либо институтами во взаимоотношениях с государством и внешним миром. В этом же разделе проведен сравнительный анализ ключевых составляющих государственно-церковных отношений в Египте и России на основе данных проекта «Религия и государство». Во втором разделе на примере взаимодействия РПЦ и Аль-Азхара рассмотрены направления первой модели взаимодействия религиозных акторов - институтов, представляющих доминирующие религии России и Египта. В третьем разделе изучена специфика взаимодействия института доминирующей религии с институтами религии меньшинства: контакты между Аль-Азхаром и Духовным управлением мусульман России (ДУМ РФ), РПЦ и Александрийской православной церковью, а также РПЦ и Коптской православной церковью (КПЦ) Египта. Наконец, заключительный раздел сфокусирован на взаимодействии (точнее, его отсутствии) шиитских общин России и Египта, не имеющих собственных религиозных институтов, которые могли бы выражать их интересы как в странах проживания, так и за рубежом.

\section{Особенности государственной политики Египта и России в отношении религии}

\section{Религиозная ситуация в современном Египте}

Согласно последнему отчету «Религиозная свобода в мире» (2020), подготовленному Госдепартаментом США, население Египта составляет 104,1 млн человек, из которых около $90 \%$ исповедует суннитский ислам и около $10 \%$ - христианство. Отмечается также, что подавляющее большинство всех 
христиан Египта причисляют себя к Коптской православной церкви, представители других течений христианства ${ }^{5}$ в совокупности составляют около $2 \%$. Менее $1 \%$ составляют иудеи, мусульмане-шииты, бахаиты, члены ордена ахмадийя и давуди бора ${ }^{6}$.

Таблича 1

Религиозная ситуация в Египте и России в 2015 г.

\begin{tabular}{|l|c|c|}
\hline \multicolumn{1}{|c|}{ Критерий } & Египет & Россия \\
\hline Население, млн чел. (2021) & $106,437,241$ & $142,320,790$ \\
\hline Официальная религия & $\begin{array}{c}\text { Суннитский } \\
\text { ислам }\end{array}$ & Православие \\
\hline \multicolumn{2}{|c|}{ Доля последователей различных религий } \\
\hline Мусульмане (всего, \%), из них: & 88,4 & 10,6 \\
\hline сунниты & 88,3 & 10 \\
\hline шииты & 0,2 & 0,7 \\
\hline другие & $>0,1$ & - \\
\hline Христиане (всего, \%), из них: & 10,9 & 48,2 \\
\hline православные & 9,3 & 44,6 \\
\hline пятидесятники & 0,3 & 1,5 \\
\hline протестанты & 1,1 & 1,1 \\
\hline католики & 0,2 & 0,5 \\
\hline другие & $>0,1$ & 0,5 \\
\hline Этнические религии \\
(анимизм, шаманизм и др.), \\
$\%$
\end{tabular}

Источник: составлено авторами по данным: Egypt // CIA. The World Factbook. URL: https://www.cia.gov/theworld-factbook/countries/egypt/\#people-and-society

(accessed: 12.08.2021); Russia // CIA. The World Factbook. URL: https://www.cia.gov/the-world-factbook/ countries/russia/\#people-and-society (accessed: 12.08.2021); Compare Nations // The ARDA. URL: https://www.thearda. com/internationalData/compare2.asp? $\mathrm{c}=73 \& \mathrm{c}=186$ (accessed: 12.08.2021).

\footnotetext{
${ }^{5}$ Среди них: англикане, Армянская Апостольская церковь, католики (армяне, халдеи, мелькиты, марониты, католики латинского обряда, сиро-католики), православные (греческого и сирийского обрядов), а также протестанты, подавляющее большинство которых принадлежит зонтичной организации Протестантских церквей Египта, или Ассоциации Евангелической церкви. См.: Egypt 2020 International Religious Freedom Report. United States Department of State, 2020. P. 3. URL: https://www.justice.gov/eoir/page/file/1395811/ download (accessed: 18.08.2021).

${ }^{6}$ Ibid.
}

В табл. 1 представлены данные о доле последователей различных религий в составе населения Египта и России на 2015 г., аккумулированные проектом «Религия и государство», которые не сильно разнятся с данными за 2020 г. по Египту, представленными выше.

Table 1

Religious situation in Egypt and Russia, 2015

\begin{tabular}{|l|c|c|}
\hline \multicolumn{1}{|c|}{ Criterion } & Egypt & Russia \\
\hline Total population, mln (2021) & $106,437,241$ & $142,320,790$ \\
\hline Official Religion & Sunni Islam & Orthodoxy \\
\hline \multicolumn{2}{|c|}{ Religious Adherents } \\
\hline $\begin{array}{l}\text { Muslim (all denominations } \\
\text { combined), \%: }\end{array}$ & 88.4 & 10.6 \\
\hline Sunni Muslim & 88.3 & 10 \\
\hline Shia Muslim & 0.2 & 0.7 \\
\hline Other and unknown Muslim & $>0.1$ & - \\
\hline $\begin{array}{l}\text { Christian (all denominations } \\
\text { combined), \%: }\end{array}$ & 10.9 & 48.2 \\
\hline Orthodox & 9.3 & 44.6 \\
\hline Pentecostal & 0.3 & 1.5 \\
\hline Protestant & 1.1 & 1.1 \\
\hline Catholic & 0.2 & 0.5 \\
\hline Other and unknown Christian & $>0.1$ & 0.5 \\
\hline $\begin{array}{l}\text { Ethnoreligionist } \\
\text { incl. Animist, Shamanist), \% }\end{array}$ & - & 1.4 \\
\hline $\begin{array}{l}\text { Buddhist (all denominations } \\
\text { combined), \%: }\end{array}$ & - & 0.5 \\
\hline Vajrayana Buddhist & - & 0.5 \\
\hline Other and unknown Buddhist & - & 0.1 \\
\hline Other Religionist, \% & $>0.1$ & 0.1 \\
\hline Not Religious (incl. Atheist), \% & 0.6 & 8.2 \\
\hline Unknown, \% & - & 31 \\
\hline Sorre: compil by & \\
\hline
\end{tabular}

Source: compiled by the authors based on the data: Egypt // CIA. The World Factbook. URL: https://www.cia.gov/ the-world-factbook/countries/egypt/\#people-and-society (accessed: 12.08.2021); Russia // CIA. The World Factbook. URL: https://www.cia.gov/the-world-factbook/ countries/russia/\#people-and-society (accessed: 12.08.2021); Compare Nations // The ARDA. URL: https://www.thearda. com/internationalData/compare2.asp? $\mathrm{c}=73 \& \mathrm{c}=186$ (accessed: 12.08.2021).

Исходя из данных табл. 1, следует, что религия занимает более важное место в жизни египтян, нежели россиян $(0,6 \%$ нерелигиозных в Египте против 8,2 \% - в России, а также $31 \%$ россиян, которые либо не придают значения религии в своей жизни, либо не могут отнести себя к конкретной религии (графа «нет данных»)), следовательно, она оказывает более существенное влияние на общественно-политические отношения в 
Египте. Также египетское общество более однородно в конфессиональном плане: 88 \% населения исповедуют ислам, при этом только $0,1 \%$ - его шиитскую версию. Согласно имеющимся данным, в России шиитская община, состоящая преимущественно из этнических азербайджанцев, часть из которых мигранты и не имеют российского гражданства, более многочисленна, чем в Египте, хотя здесь требуется оговорка: в странах, где наблюдается дискриминация в отношении шиитского населения, шииты могут воспользоваться принципом сокрытия своей веры (ат-такыйя) ради выживания, что осложняет процесс подсчета численности шиитов в некоторых государствах и относительность доступных показателей.

Что же касается христиан, то в обеих странах подавляющее большинство составляют православные. Однако проект «Религия и государство» Университета Бар-Илана не выделил в отдельную группу христианкоптов Египта, которые отрицают решения Халкидонского Вселенского собора 451 г., ключевым вопросом которого был христологический спор (о природе и воле Иисуса Христа), поэтому Коптская православная церковь относится к дохалкидонским церквам, в то время как РПЦ признает решения этого собора, что делает ее частью сообщества халкидонских церквей (El Masri, 1978, p. 276). Между церквами двух разных обрядов отсутствует евхаристическое общение (возможность совместного служения), поэтому в дальнейшем мы будем различать отношения РПЦ с Александрийским патриархатом (халкидонская церковь, евхаристическое общение с РПЦ было до 2019 г.) и отношения РПЦ с Коптской церковью.

\section{Государственно-церковные отношения в России и Ezunme: сравнительный анализ}

Данные проекта «Религия и государство» позволяют выявить ключевые сходства и различия политики Египта и России в отношении религиозных общин, причем учитывая, являются члены той или иной общины последователями доминирующей религии - в нашем случае суннитского ислама в Египте и православного христианства в России или религиозным меньшинством. Сравнение проводится по ряду критериев, среди которых государственное регулирование религиозной сферы, наличие дискриминации по религиозному признаку, государственное финансирование религии и др. (табл. 2).

Данные, представленные в табл. 2, не противоречат тому факту, что, согласно основным законам двух стран, в Египте ислам признан государственной религией, а в России «никакая религия не может устанавливаться в качестве государственной или обязательной» ${ }^{7}$. Так, о значительном контроле религиозной сферы со стороны государства свидетельствуют показатели 1, 3, 5 и 6 табл. 2. Значения для России по указанным показателям ниже (кроме показателя 6), что свидетельствует о более низком уровне контроля религии со стороны государства.

Показатели 9, 11 и 13, отражающие официальный религиозный статус, представленность в религиозном образовании и финансовую поддержку государством доминирующей религии - суннитского ислама в Египте и православия в России, - свидетельствуют о безусловной поддержке Египтом религиозных институтов суннизма и его высоком статусе, среднее значение (2 из 4) демонстрирует только показатель о требованиях к религиозному образованию. В свою очередь, по России несколько ниже только показатели 9 и 13, в то время как требования к религиозному образованию также показывают среднее значение, что объясняют данные табл. 3, где отмечается, что в российских школах ученик (в частности, исповедующий другую религию) вправе отказаться от курса по основам православия.

Остальные показатели в табл. 2 относятся к государственной политике двух стран в отношении религиозных меньщинств. Что

${ }^{7}$ П. 1 ст. 14 Конституции Российской Федерации (принята на всенародном голосовании 12 декабря 1993 г.) (с изменениями, одобренными в ходе общероссийского голосования 1 июля 2020 г.). URL: http:/ivo.garant.ru/\#/document/10103000/paragraph/92:0 (дата обращения: 20.09.2021). 
касается Египта, то данные таблицы демонстрируют достаточно высокую (но не максимальную) степень ущемления религиозных меньшинств (показатель 2), особенно в социальной сфере (показатель 4), а также большое количество жертв преследований по религиозным соображениям (показатель 8). Очень низким оказался статус религиозных меньшинств в Египте (показатель 10), что подтверждается также низкими требованиями к религиозному образованию недоминирующих религий (показатель 12) и отсутствие их финансирования со стороны государства (показатель 14).

Сравнение ключевых индексов государственной политики Египта и России

Таблица 2 в отношении религии

\begin{tabular}{|c|c|c|c|}
\hline № & Индекс & Египет & Россия \\
\hline 1 & $\begin{array}{l}\text { Государственное регулирование большинства или всех религий }(0-87 \text {, чем ниже } \\
\text { индекс, тем меньше степень регулирования) }\end{array}$ & 29 & 17 \\
\hline 2 & $\begin{array}{l}\text { Индекс дискриминации религиозных меньшинств со стороны государства }(0-108, \\
\text { чем ниже индекс, тем меньше степень дискриминации) }\end{array}$ & 46 & 49 \\
\hline 3 & $\begin{array}{l}\text { Государственное финансирование религии }(0-10 \text {, чем ниже индекс, тем меньше } \\
\text { уровень финансирования) }\end{array}$ & 6 & 4 \\
\hline 4 & $\begin{array}{l}\text { Индекс социальной дискриминации религиозных меньшинств }(0-81 \text {, чем ниже ин- } \\
\text { декс, тем меньше степень дискриминации) }\end{array}$ & 62 & 26 \\
\hline 5 & $\begin{array}{l}\text { Индекс религиозного законодательства }(0-52, \text { чем ниже индекс, тем меньше зако- } \\
\text { нодательного контроля в сфере религии) }\end{array}$ & 28 & 12 \\
\hline 6 & $\begin{array}{l}\text { Средний балл социального регулирования по кодировке ARDA по данным отчетов } \\
\text { Государственного департамента США о международной религиозной свободе за } \\
2003,2005 \text { и } 2008 \text { гг. (0-10, чем ниже индекс, тем меньше степень регулирования) }\end{array}$ & 8 & 9,8 \\
\hline 7 & $\begin{array}{l}\text { Сводная оценка свободы вероисповедания для недоминирующих религий }(0-4, \text { чем } \\
\text { ниже индекс, тем больше уровень свободы) }\end{array}$ & 1,3 & 2,0 \\
\hline 8 & $\begin{array}{l}\text { Среднее количество людей, подвергшихся физическому насилию, перемещению, } \\
\text { заключению в тюрьму или убитых из-за их религии, согласно отчетам Государ- } \\
\text { ственного департамента США о свободе вероисповедания за } 2005 \text { и } 2008 \text { гг. } \\
\text { (кодировка ARDA). } 0=\text { нет; } 1=1-10 ; 2=11-20 ; 3=21-100 ; 4=101-500 ; \\
5=501-1000 ; 6=1001-5000 ; 7=5001-10000 ; 8=10001-50 \text { 000; } \\
9=50001-100000 ; 10=\text { больше } 100000 \text { чел. }\end{array}$ & 7 & 3 \\
\hline 9 & $\begin{array}{l}\text { Официальный религиозный статус - совокупный балл для предпочитаемой / офи- } \\
\text { циальной религии }(0-4, \text { чем ниже балл, тем ниже статус })\end{array}$ & 3,5 & 3 \\
\hline 10 & $\begin{array}{l}\text { Официальный религиозный статус - совокупный балл для религий меньшинства } \\
(0-4, \text { чем ниже балл, тем ниже статус) }\end{array}$ & 0,5 & 1 \\
\hline 11 & $\begin{array}{l}\text { Религиозное образование - совокупный балл для предпочитаемой / официальной } \\
\text { религии }(0-4, \text { чем ниже балл, тем меньше требования) }\end{array}$ & 2 & 2 \\
\hline 12 & $\begin{array}{l}\text { Религиозное образование — совокупный балл для религий меньшинства }(0-4 \text {, чем } \\
\text { ниже балл, тем меньше требования) }\end{array}$ & 1 & 1 \\
\hline 13 & $\begin{array}{l}\text { Финансовая поддержка - совокупный балл для предпочитаемой / официальной } \\
\text { религии }(0-4 \text {, чем ниже балл, тем меньше поддержка) }\end{array}$ & 4 & 2 \\
\hline 14 & $\begin{array}{l}\text { Финансовая поддержка — совокупный балл для религий меньшинства }(0-4 \text {, чем } \\
\text { ниже балл, тем меньше поддержка) }\end{array}$ & 0 & 2 \\
\hline
\end{tabular}

Примечание. Исследование проводилось в 1990-2015 гг., однако данные для показателей 6 и 8 рассчитаны на основании кодирования отчетов Госдепартамента США о религиозной свободе в мире за 2003, 2005 и 2008 г. с применением методики кодирования Б. Грима и Р. Финке (Grim \& Finke, 2006).

Источник: составлено авторами по данным: Compare Nations // The ARDA. URL: https://www.thearda.com/internationalData/compare3.asp?c=73\&c=186 (accessed: 02.09.2021); Religious Regulations Compare Nations // The ARDA. URL: https:/www.thearda.com/internationalData/compare4.asp? $=73 \& \mathrm{c}=186$ (accessed: 02.09.2021). 
Comparison of key indices of government policy in Egypt and Russia in relation to religion

\begin{tabular}{|c|c|c|c|}
\hline No. & Index & Egypt & Russia \\
\hline 1 & State Regulation of Majority or All Religions Index ( $0-87$, lower means less regulation) & 29 & 17 \\
\hline 2 & State Religious Minority Discrimination Index $(0-108$, lower means less discrimination) & 46 & 49 \\
\hline 3 & State Funding of Religion Summary ( $0-10$, lower means less state funding) & 6 & 4 \\
\hline 4 & $\begin{array}{l}\begin{array}{l}\text { Societal Discrimination of Minority } \\
\text { discrimination) }\end{array}\end{array}$ & 62 & 26 \\
\hline 5 & Religious Legislation Index ( $0 \_52$, lower means less religious legislation) & 28 & 12 \\
\hline 6 & $\begin{array}{l}\text { Average social regulation score over ARDA researchers' coding of } 2003,2005 \text { and } 2008 \\
\text { U.S. Department of State's International Religious Freedom Reports }(0-10 \text {, lower means } \\
\text { less regulation) }\end{array}$ & 8 & 9.8 \\
\hline 7 & $\begin{array}{l}\text { Religious Freedom Composite Score for Nonpreferred Religion(s) }(0-4 \text {, lower means more } \\
\text { freedom) }(2015)\end{array}$ & 1.3 & 2.0 \\
\hline 8 & $\begin{array}{l}\text { Average number of people physically abused, displaced, imprisoned, or killed due to their } \\
\text { religion according to the U.S. Department of State's } 2005 \text { and } 2008 \text { International Religious } \\
\text { Freedom Reports (as coded by ARDA researchers). } 0=\text { None; } 1=1-10 ; 2=11-20 \text {; } \\
3=21-100 ; 4=101-500 ; 5=501-1000 ; 6=1001-5000 ; 7=5001-10000 \\
8=10001-50000 ; 9=50001-100000 ; 10=\text { greater than } 100000\end{array}$ & 7 & 3 \\
\hline 9 & $\begin{array}{lcccccc}\begin{array}{l}\text { Religious } \\
(0-4, \text { Official }\end{array} & \text { Status } & \text { Composite } & \text { Score } & \text { of } & \text { Preferred } & \text { Religion(s) } \\
\end{array}$ & 3.5 & 3 \\
\hline 10 & $\begin{array}{lccccc}\begin{array}{l}\text { Religious } \\
(0-4, \text { Official }\end{array} \text { Status } & \text { Composite } & \text { Score } & \text { of } & \text { Nonpreferred } & \text { Religion(s) } \\
\end{array}$ & 0.5 & 1 \\
\hline 11 & $\begin{array}{l}\text { Religious Education Composite Score of Preferred Religion(s) }(0-4 \text {, lower means less } \\
\text { religious education requirements) }\end{array}$ & 2 & 2 \\
\hline 12 & $\begin{array}{l}\text { Religious Education Composite Score of Nonpreferred Religion(s) }(0-4 \text {, lower means less } \\
\text { religious education requirements) }\end{array}$ & 1 & 1 \\
\hline 13 & $\begin{array}{l}\text { Religious Financial Support Composite Score of Preferred Religion(s) }(0-4 \text {, lower means } \\
\text { less financial support) }\end{array}$ & 4 & 2 \\
\hline 14 & $\begin{array}{l}\text { Religious Financial Support Composite Score of Nonpreferred Religion(s) }(0-4 \text {, lower } \\
\text { means less financial support) }\end{array}$ & 0 & 2 \\
\hline
\end{tabular}

Note. The study was conducted in 1990-2015; however, the data for indicators 6 and 8 were calculated based on the coding of the International Religious Freedom Reports of the US Department of State for 2003, 2005 and 2008 using the coding methodology of B. Grim and R. Finke (Grim \& Finke, 2006).

Source: compiled by the authors based on the data: Compare Nations // The ARDA. URL: https://www.thearda.com/ internationalData/compare3.asp?c=73\&c=186 (accessed: 02.09.2021); Religious Regulations - Compare Nations // The ARDA. URL: https://www.thearda.com/internationalData/compare4.asp?c=73\&c=186 (accessed: 02.09.2021).

Любопытен в этой связи показатель 7, который демонстрирует казалось бы противоречащую всем остальным пунктам достаточно низкую сводную оценку свободы вероисповедания для недоминирующих религий (1,3 из 4). Однако это можно объяснить тем, что, согласно Конституции Египта, религиозный и личный статус христиан и иудеев регулируется в соответствии с их собственными религиозными законами, что фактически приравнивает их по статусу к мусульманам (подробнее об этом ниже). Это, как представляется, несколько размывает общий балл Египта.
Оценки политики России в отношении религиозных меньшинств значительно расходятся с баллами Египта по таким параметрам, как дискриминация в социальной сфере (показатель 4): результаты России свидетельствуют о достаточно развитых свободах для религиозных меньшинств и среднем уровне дискриминации ${ }^{8}$; среднее количество людей,

\footnotetext{
8 «Каждому гарантируется свобода совести, свобода вероисповедания, включая право исповедовать индивидуально или совместно с другими любую религию или не исповедовать никакой, свободно выбирать, иметь и распространять религиозные и иные убеждения и действовать в соответствии с ними» (ст. 28 Конституции
} 
пострадавших за свои религиозные убеждения (до 100 человек) (показатель 8); финансовая поддержка религиозных меньшинств (2 из 4, 0 - у Египта) (показатель 14). По остальным показателям значения двух стран очень близки.

Табл. 3 содержит критерии сравнения политики Египта и России в отношении религии, среди которых легальность прозелитизма, специфика финансирования религиозных институтов доминирующей религии, обязательность религиозного образования и необходимость регистрации религиозных организаций.

Особенности государственной политики

Таблища 3

Египта и России в отношении религии

\begin{tabular}{|c|c|c|}
\hline Критерий & Египет & Россия \\
\hline $\begin{array}{l}\text { Легальность } \\
\text { прозелитизма }\end{array}$ & & Да \\
\hline \begin{tabular}{|l} 
Официальные \\
отношения \\
между религией \\
и государством
\end{tabular} & \begin{tabular}{|l|} 
Религия \\
контролируется \\
государством, \\
позитивное \\
отношение
\end{tabular} & Многоуровневые \\
\hline $\begin{array}{l}\text { Обязательность } \\
\text { религиозного } \\
\text { образования в } \\
\text { государственных } \\
\text { школах }\end{array}$ & $\begin{array}{l}\text { Обязательно } \\
\text { для всех }\end{array}$ & $\begin{array}{l}\text { Обязательно, но } \\
\text { по особому запро- } \\
\text { су обучающийся } \\
\text { может отказаться } \\
\text { от курса }\end{array}$ \\
\hline $\begin{array}{l}\text { Финансирование } \\
\text { государственной } \\
/ / \text { доминирующей } \\
\text { религии } \\
\end{array}$ & \multicolumn{2}{|c|}{$\begin{array}{l}\text { Государственное финансирование } \\
\text { религии идет в основном на одну } \\
\text { религию, другие религии также } \\
\text { получают определенные средства }\end{array}$} \\
\hline $\begin{array}{l}\text { Необходимость } \\
\text { регистрации } \\
\text { религиозных } \\
\text { организаций }\end{array}$ & \multicolumn{2}{|c|}{$\begin{array}{l}\text { Регистрация требуется, но иногда } \\
\text { в ней отказывают }\end{array}$} \\
\hline $\begin{array}{l}\text { Последствия } \\
\text { регистрации } \\
\text { религиозных } \\
\text { организаций }\end{array}$ & \multicolumn{2}{|c|}{$\begin{array}{l}\text { Группы официально обязаны ре- } \\
\text { гистрироваться; незарегистриро- } \\
\text { ванные группы могут подвергать- } \\
\text { ся преследованиям. }\end{array}$} \\
\hline
\end{tabular}

Источник: составлено авторами по данным: Compare Nations // The ARDA. URL: https://www.thearda.com/ internationalData/compare3.asp? $\mathrm{c}=73 \& \mathrm{c}=186$ (accessed: 02.09.2021); Religious Freedom - Compare Nations // The ARDA. URL: https://www.thearda.com/international Data/compare4.asp? $\mathrm{c}=73 \& \mathrm{c}=186$ (accessed: 02.09.2021); Religious Regulations - Compare Nations // The ARDA. URL: https://www.thearda.com/internationalData/compare 5.asp? $\mathrm{c}=73 \& \mathrm{c}=186$ (accessed: 02.09 .2021$)$.

Российской Федерации (принята на всенародном голосовании 12 декабря 1993 г.) (с изменениями, одобренными в ходе общероссийского голосования 1 июля 2020 г.). URL: http://ivo.garant.ru/\#/document/10103000/ paragraph/154:0 (дата обращения: 20.09.2021)).
Features of the state religion policy of Egypt and Russia

\begin{tabular}{|l|l|l|}
\hline \multicolumn{1}{|c|}{ Criterion } & \multicolumn{1}{|c|}{ Egypt } & \multicolumn{1}{c|}{ Russia } \\
\hline Is proselytizing Legal? & \multicolumn{2}{|c|}{ Yes } \\
\hline $\begin{array}{l}\text { Official Support: The } \\
\text { formal relationship } \\
\text { between religion and } \\
\text { state }\end{array}$ & $\begin{array}{l}\text { State } \\
\text { controlled } \\
\text { religion, } \\
\text { positive } \\
\text { attitude }\end{array}$ & $\begin{array}{l}\text { pulti-tiered } \\
\text { preferences }\end{array}$ \\
\hline
\end{tabular}

The extent to which Mandatory for Mandatory, but religious education is all; the course upon specific mandatory in public must be in request, a student \begin{tabular}{|l|l|}
\hline schools & religion \\
\hline
\end{tabular} The extent to which Government funding of religion funding is exclusive to goes primarily to one religion one or a few religions but at least some other religions receive some funds

Is religious registration Registration is required but sometimes denied? sometimes denied

What are the Groups are officially required to consequences of register, and the government registration? enforces this and discriminates against unregistered groups.

Source: compiled by the authors based on the data: Compare Nations // The ARDA. URL: https://www.thearda. com/internationalData/compare 3 .asp? $\mathrm{c}=73 \& \mathrm{c}=186$ (accessed: 02.09.2021); Religious Freedom - Compare Nations // The ARDA. URL: https://www.thearda.com/international Data/compare4.asp?c=73\&c=186 (accessed: 02.09.2021); Religious Regulations - Compare Nations // The ARDA. URL: https://www.thearda.com/internationalData/compare 5.asp? $=73 \& \mathrm{c}=186$ (accessed: 02.09.2021).

Данные табл. 3 демонстрируют сходство политики российского и египетского правительств в отношении религии по трем критериям из пяти, что подтверждают и индексы, отраженные в табл. 2. При этом отношения между религией и государством в Египте более определенные, что объясняется статусом ислама как государственной религии, находящейся под контролем государства и служащей его интересам, в то время как в России государственно-церковные отношения многоуровневые, что обусловлено как конфессиональным разнообразием (табл. 1), так и безоговорочно светским характером Российского государства.

Исходя из вышеизложенного, можно выделить четыре модели взаимодействия религиозных акторов: 1) доминирующая религия + доминирующая религия; 2) доминирующая религия + религиозное меньшинство; 
3) религиозное меньшинство + религиозное меньшинство; 4) взаимодействие религиозных меньшинств, не представленных какимлибо институтом. Рассмотрим особенности каждой из этих моделей.

\section{Диалог по линии институтов доминирующих религий: РПЦ и Аль-Азхар}

Согласно ст. 7 Конституции Арабской Республики Египет, «Аль-Азхар - независимое научное исламское учреждение, обладающее исключительной компетенцией в своих делах. Это главный авторитет в области религиозных наук и исламских дел. Он отвечает за проповедь ислама и распространение религиозных наук и арабского языка в Египте и во всем мире. Государство должно выделять достаточно финансовых средств для достижения этих целей. Великий шейх Аль-Азхара независим и не может быть уволен. Порядок назначения Великого шейха из числа членов Совета старших ученых определяется законом» 9 .

В свою очередь, РПЦ является неправительственной организацией, глава которой патриарх - также избирается независимо от государства и не может быть смещен с должности по его воле. При этом РПЦ не обладает каким-либо особым статусом, поскольку «религиозные объединения отделены от государства и равны перед законом» ${ }^{10}$.

РПЦ взаимодействует с Аль-Азхаром в рамках межрелигиозного диалога, координацию которого со стороны Московского патриархата осуществляет Отдел внешних церковных связей (ОВЦС).

Двусторонние встречи деятелей РПЦ с руководством университета имели место в

\footnotetext{
${ }^{9}$ Egypt's Constitution of 2014. URL: https://www.constituteproject.org/constitution/Egypt_2014 .pdf (accessed: 13.09.2021).

${ }^{10}$ П. 2 ст. 14 Конституции Российской Федерации (принята на всенародном голосовании 12 декабря 1993 г.) (с изменениями, одобренными в ходе общероссийского голосования 1 июля 2020 г.). URL: http://ivo.garant.ru/\#/document/10103000/paragraph/94:0 (дата обращения: 20.09.2021)
}

2010 и 2011 гг. $^{11}$, и в ходе данных встреч обсуждались главным образом проблемы противодействия радикализму и экстремизму, а также преследований за веру. В частности, в ходе совпавшего по времени с событиями «арабской весны» визита главы ОВЦС митрополита Илариона РПЦ выразила озабоченность положением христианского населения Ближнего Востока и Африки, рассматривая межрелигиозный диалог как перспективу, «которая обеспечит христианам Ближнего Востока мирное и уважительное отношение со стороны мусульманского большинства"12. В частности, митрополит поддержал выдвинутую шейхом ат-Тайебом идею создания организации «Наш дом - Египет», членами которой были бы как мусульманские, так и христианские деятели, которые совместно будут «вести работу по укреплению межрелигиозных связей, бороться с распространением радикальных взглядов и призывать египтян к национальному единству независимо от конфессиональной принадлежности» ${ }^{13}$.

Примечательно, как деятели РПЦ высказываются об образовании, которые российские мусульмане получают в Аль-Азхаре: «Университет Аль-Азхар - заведение очень сдержанное, классическое, суннитское мусульманское, и его выпускники, возвращаясь к нам в Россию, кроме света религии ничего с собой не привозят. Но есть же другие места,

${ }^{11}$ См.: Русская православная церковь начнет сотрудничать с исламским университетом «Аль-Азхар» // Интерфакс. 12.10.2010. URL: http://www.interfaxreligion.ru/islam/index.php?act $=$ news\&div $=35121$ дата обращения: 01.10.2021); Председатель Отдела внешних церковных связей провел встречу с заместителем генерального секретаря Лиги арабских государств // РПЦ. 03.09.2021. URL: http://www.patriarchia.ru/db/text/ 5840385.html (дата обращения: 01.10.2021).

12 Выступление митрополита Волоколамского Илариона на совместной конференции Русской Православной Церкви и Евангелической церкви в Германии «Мученики, мученичество, христианское свидетельство» // РПЦ. 02.11.2017. URL: http://www.patriarchia.ru/ $\mathrm{db} / \mathrm{text} / 5053661 . h t m l$ (дата обращения: 01.10.2021).

${ }^{13}$ Состоялась встреча председателя Отдела внешних церковных связей Московского Патриархата с Верховным имамом университета Аль-Азхар // РПЦ. 14.06.2011. URL: http://www.patriarchia.ru/db/text/ 1541001.html (дата обращения: 01.10.2021). 
куда ездят учиться наши мусульмане, где проповедуют совсем другие идеи» ${ }^{14}$. Однако очевидно, что данное высказывание оставляет за скобками проблему радикализации студентов Аль-Азхара, проявляющуюся в популярности таких проповедников, как идеолог «Братьев-мусульман» ${ }^{15}$ Юсуф аль-Кардауи, который выступает против действующего египетского режима в лице президента А. ас-Сиси ${ }^{16}$, а также называет Россию «врагом ислама» ${ }^{17}$.

Чаще всего взаимодействие РПЦ и АльАзхара осуществляется на многосторонних площадках, в рамках международных конференций и форумов, объединяющих представителей различных религиозных общин. Целью подобных мероприятий, как правило, является привлечение внимания мирового сообщества к консолидированной позиции религиозных деятелей по защите мира.

Среди стимулов продвижения диалога двух институтов, представляющих интересы доминирующих религий России и Египта, в последние годы центральную роль играет общая для христианства и ислама проблема религиофобии, уходящей корнями в деятельность многочисленных экстремистских группировок на Ближнем Востоке, которые выбирают в качестве объекта для преследований представителей религиозных меньшинств или тех, кто не разделяет их «идеалов» - будь то их единоверцы или последователи других религий. Взаимодействию также способствует высокий уровень государственной поддержки РПЦ и Аль-Азхара, которые фактически являются выразителями интересов и взглядов

14 Митрополит Волоколамский Иларион: Для того чтобы представители разных народов и религий жили в мире и согласии, нужна крепкая государственная власть // РПЦ. 02.03.2015. URL: http://www.patriarchia.ru/ $\mathrm{db} / \mathrm{text} / 2322704 . \mathrm{html}$ (дата обращения: 01.10.2021).

15 Организация запрещена в РФ.

${ }^{16}$ Qaradawi's Fatwa Bans Voting in Egypt Elections // Al-Arabiya. May 12, 2014. URL: https://english.alarabiya.net/ News/middle-east/2014/05/12/Qatar-based-cleric-calls-forEgypt-vote-boycott- (accessed: 01.10.2021).

${ }^{17}$ Russia Islam's No. 1 Enemy? Russia's Grand Mufti responds to Shaykh al-Qaradawi // Muslimvillage.com. November 23, 2021. URL: https://muslimvillage.com/ 2012/11/23/32029/russia-islams-no-1-enemy-russiasgrand-mufti/ (accessed: 01.10.2021). правительств России и Египта в вопросах религии (табл. 2 и 3 ).

Что же касается ограничений диалога, то они связаны скорее со статусом и полномочиями Московского патриархата, которому очень сложно соперничать с Римской католической церковью (РКЦ) в вопросах активизации межрелигиозного диалога с исламом. РПЦ не имеет тех финансовых, имиджевых и дипломатических средств, которыми обладает Святой Престол, будучи полноправным государством с развитой сетью дипломатических представительств за рубежом. Здесь также следует упомянуть и фактор личности папы Франциска, который избрал одной из своих главных целей укрепление контактов с инославными христианскими церквами и нехристианскими сообществами (Данненберг, Касаткин, 2018). В 2015 г. Ватикан (наряду с Россией и Ливаном) был одним из инициаторов принятия Советом ООН по правам человека заявления в защиту христиан Ближнего Востока, где впервые катастрофическое положение христианских общин региона названо «геноцидом» ${ }^{18}$. В подготовке данного документа с российской стороны значительную роль сыграла и РПЦ, которая одной из первых забила тревогу в СМИ и на международных площадках относительно гонений на ближневосточных христиан ${ }^{19}$. Тем не менее среди инициаторов заявления РПЦ по понятным причинам не значится.

\section{Взаимодействие института доминирующей религии с институтами религии меньшинства}

\section{ДУМ РФ -Аль-Азхар}

Взаимодействие исламских религиозных институтов Египта и России развивается достаточно активно. Партнером Аль-Азхара

${ }^{18}$ На сессии Совета по правам человека ООН впервые принято заявление в защиту христиан Ближнего Востока // РПЦ. 18.03.2015. URL: http://www.patriarchia.ru/ $\mathrm{db} / \mathrm{text} / 4015461 . h t m l$ (дата обращения: 11.11.2020).

19 Митрополит Волоколамский Иларион: Задача религиозных лидеров всех традиционных конфессий - борьба с радикализмом // РПЦ. 03.02.2011. URL: http://www.patriarchia.ru/db/text/1401182.html (дата обращения: 11.09.2020). 
по диалогу выступает Духовное управление мусульман Российской Федерации - централизованная религиозная организация, имеющая официальную регистрацию в Минюсте РФ. Договорно-правовая база диалога включает Меморандум о сотрудничестве между генеральным секретариатом управлений и ведомств по фетвам в странах мира, действующим при Управлении по фетвам Арабской Республики Египет, и Духовным управлением мусульман Российской Федерации (подписан 21 декабря 2020 г.).

Одним из ключевых вопросов сотрудничества ДУМ РФ и Аль-Азхара является исламское образование. Для России проблема возрождения системы исламского образования после 70-летнего периода господства атеизма стоит особенно остро, а пока эта проблема не решена - естественным выходом является направление будущих мусульманских религиозных деятелей на обучение за рубеж, в том числе в один из крупнейших центров исламского образования - египетский Университет Аль-Азхар. Самые ранние сообщения о намерениях советской стороны договориться с Египтом о направлении своих студентов в этот университет, которые авторам удалось обнаружить в архивных документах, датируются 1947 г. $^{20}$

Среди выпускников Аль-Азхара, составляющих интеллектуальную элиту российских мусульман, необходимо в первую очередь отметить богословов-реформаторов Мусу Бигеева и Зия Камали ${ }^{21}$. По данным на 2016 г. (более свежих данных в официальных источниках обнаружить не удалось), в Аль-Азхаре обучалось 920 российских студентов ${ }^{22}$. Среди

20 Государственный архив Российской Федерации (ГА РФ). Ф. Р-6991. Оп. 1. Д. 14. Л. 140. Египетская пресса о церкви и религии в СССР. 1947 г.

${ }^{21}$ Муса Бигеев (1873-1949) - выдающийся татарский философ-богослов, публицист, один из лидеров прогрессивного движения (джадидизм) среди мусульман России начала ХХ в. Зия Камали (1873-1942) татарский философ-реформатор, ученик Мухаммада Абдо.

22 Меморандум между ДУМ РФ и Домом фетв Египта вписывается в повестку российско-египетских и российско-африканских взаимоотношений // Духовное управление мусульман Российской Федерации. ключевых фигур российского мусульманского сообщества выпускниками Аль-Азхара являются Айнур Биргалин, председатель Духовного управления мусульман и муфтий Башкортостана, и Ильдар Аляутдинов, муфтий Москвы.

Второе направление взаимодействия Аль-Азхара и ДУМ РФ - обмен опытом методологии вынесения фетв и мусульманского богословия. В рамках данного направления высококвалифицированные сотрудники Управления по делам фетв выступают в качестве приглашенных специалистов на заседаниях Совета улемов ДУМ РФ ${ }^{23}$. Последнее по времени подобное выступление имело место 21 декабря 2020 г., когда перед Советом улемов ДУМ РФ выступили советник муфтия Египта по религиозным вопросам, доктор шариатских наук Магди Ашур и руководитель центра обучения Управления по делам фетв Египта Амр аль-Варданий ${ }^{24}$.

Следующее направление - духовнопросветительское сотрудничество и интеллектуальные обмены, которые приобретают особое значение в условиях растущей исламофобии (а в более широком смысле - религиофобии), активного распространения идей экстремизма и терроризма. Российская сторона осуществляет переводы на русский язык богословских трудов и работ по общественно-политической проблематике ведущих египетских мыслителей: «Трактат о единобожии» исламского теолога, философа и общественного деятеля, Верховного муфтия Египта Мухаммада Абдо ${ }^{25}$, «Диалог реформатора

21.12.2020. URL: http://dumrf.ru/regions/77/opinions/ 18229 (дата обращения: 22.07.2021).

23 Рушан Аббясов обсудил с послом Египта в РФ Ихабом Насером вопросы сотрудничества // Духовное управление мусульман Российской Федерации. 02.02.2021. URL: http://dumrf.ru/regions/77/event/18410 (дата обращения: 22.07.2021).

${ }^{24}$ Совет улемов ДУМ РФ подвел итоги деятельности в 2020 г. // Духовное управление мусульман Российской Федерации. 28.12.2020. URL: http://dumrf.ru/ regions/77/event/18295 (дата обращения: 22.07.2021).

25 Презентация книжной серии «Возрождение и обновление» состоится 12 апреля в Московской Соборной мечети // Духовное управление мусульман Российской Федерации. 08.04.2021. URL: http://dumrf.ru/regions/ 77/announcement/18757 (дата обращения: 22.07.2021). 
и мукаллида» Мухаммада Рашида Риды, «Ислам: вероучение и закон» Махмуда Шальтута, «Освобождение женщины» Касима Амина, «Ислам и принципы правления» Али Абдарразика, «Реформация исламской мысли» Насра Хамида Абу Зайда и др. ${ }^{26}$ В свою очередь, египетская сторона осуществляет переводы на русский язык избранных изданий Министерства вакфов Египта, в том числе работ по исламскому богословию ${ }^{27}$. В Университете Аль-Азхар также издаются и изучаются труды татарского ученого и богослова Шихабуддина Марджани.

Таким образом, Аль-Азхар и ДУМ РФ, объединенные общей религией, сотрудничают по целому ряду направлений, по объективным причинам отсутствующих среди вопросов, по которым ведется диалог АльАзхара с РПЦ. Тем не менее, на наш взгляд, взаимодействие двух мусульманских религиозных институтов все же ограничено статусом ДУМ РФ как одной из многочисленных религиозных организаций России. Управление представляет всех российских мусульман, что является его безусловным достоинством, однако организации пока не удалось выстроить эффективную модель работы на международной арене, о чем свидетельствует, в частности, отсутствие данных о количестве студентов из России, обучающихся в зарубежных исламских университетах, то есть не только в Египте, но и других странах, хотя исламское образование - ключевое направление деятельности ДУМ РФ.

\footnotetext{
${ }^{26}$ См.: Делегация ДУМ РФ встретилась в Каире с министром вакфов Египта Мухаммадом Мухтаром Гомаа // Духовное управление мусульман Российской Федерации. 15.03.2021. URL: http://dumrf.ru/common/ event/18608 (дата обращения: 22.07.2021); Рушан Аббясов обсудил с послом Египта в РФ Ихабом Насером вопросы сотрудничества // Духовное управление мусульман Российской Федерации. 02.02.2021. URL: http://dumrf.ru/regions/77/event/18410 (дата обращения: 22.07.2021).

27 Делегация ДУМ РФ встретилась в Каире с министром вакфов Египта Мухаммадом Мухтаром Гомаа // Духовное управление мусульман Российской Федерации. 15.03.2021. URL: http://dumrf.ru/common/event/ 18608 (дата обращения: 22.07.2021).
}

\section{РПЦ - Александрийский патриархат}

Александрийская православная церковь (АПЦ), каноническая территория которой охватывает Египет (за исключением южной части Синая), а также страны Северной, Центральной и Южной Африки, включает в себя 31 епархию, 6 монастырей и около 1000 приходов. Количество прихожан составляет порядка 500 тыс. египтян (включая египетские диаспоры за рубежом) и около 6,3 млн жителей стран Африки ${ }^{28}$. Александрийский патриархат наряду с Константинопольским, Римским (до отпадения в 1054 г.), Антиохийским и Иерусалимским составляет древнюю «пентархию» православных церквей. Однако в настоящее время этот статус остается лишь символическим: как отмечают О.Е. Петрунина, Л.А. Герд и К.А. Вах, «после османского завоевания Александрийская церковь фактически утратила самостоятельность, попав в зависимость от Константинопольского патриархата. Крайняя бедность, политическая неустойчивость в период правления мамелюков, иноверная власть, продолжающееся сокращение паствы - все это привело к тому, что от прежнего величия Египетской церкви осталось одно воспоминание» (Петрунина и др., 2020 , с. 37). Серьезным ударом по статусу Александрийского патриархата и его политическому влиянию стало и снижение роли Александрии в средиземноморской торговле.

Одним из главных ограничений, всегда препятствовавших контактам православных Египта с Россией, было то, что православная община Египта состоит преимущественно из торговцев греческого происхождения, проживавших в Каире и Александрии; арабыхристиане Египта в большинстве своем принадлежат к Коптской церкви. Как известно, патриархаты греческого обряда, возглавляемые Константинополем, противостоят росту влияния РПЦ, что ярко продемонстрировал кризис вокруг автокефалии Православной церкви Украины, о котором будет сказано

\footnotetext{
${ }^{28}$ Поместные православные церкви // Монастырский хронограф. 24.01.2017. URL: http://monasterium.by/ biblioteka/infografika/pomestnye-pravoslavnye-tserkvi/ (дата обращения: 16.08.2021).
} 
ниже. Кроме того, внутри греческой паствы АПЦ наблюдалось противостояние различных богатых семейств, каждое из которых стремилось оказывать влияние на управление церковными делами, главным образом финансовыми. Кроме того, греческие подданные, составлявшие основу православной общины Египта, следуя за своим родным правительством, избрали прозападную ориентацию - на Англию или Францию, с которыми у них были установлены более тесные торговые и коммерческие отношения (Петрунина и др., 2020, с. 45).

Таким образом, исходя из сложившегося положения, у России сохранялся единственный инструмент косвенного влияния на политическую ситуацию в Египте - оказание регулярной материальной помощи православному духовенству в этой стране. Финансовая поддержка была направлена на противодействие распространению католицизма и протестантизма на Ближнем Востоке, осуществлявшееся при поддержке Парижа и Лондона. Когда после Октябрьской революции 1917 г. материальная помощь от Москвы прекратилась, Российское правительство утратило важный канал взаимодействия с Египтом. Но здесь важную роль сыграла РПЦ: в 1956 г. в Троицкой церкви в Одессе начало функционировать Патриаршее Александрийское подворье. РПЦ на регулярной основе выдавала из доходов Одесского подворья суммы на расходы экзарха (настоятеля Александрийского подворья), а остальное высылала в Александрию непосредственно патриарху. В 1999 г. подворье было перенесено в Храм всех Святых на Кулишках в Москве.

В 2019 г. по причине разногласий относительно признания Александрийским патриархатом вслед за Константинополем автокефалии Православной церкви Украины Священный Синод Московского патриархата принял решение о приостановке деятельности подворья. Кроме того, представительство Патриарха Московского и всея Руси при Патриархе Александрийском было решено преобразовать в приход Русской православной церкви в Каире. Приходы РПЦ, находящиеся на Африканском континенте, были выведены из юрисдикции Александрийского патриархата и получили ставропигиальный статус ${ }^{29}$.

На отношениях РПЦ и АПЦ очень заметно отражается давнее противостояние между Московской и Константинопольской патриархиями, соперничающими за реальное лидерство в мировом православии и отстаивающими противоположные парадигмы церковного устройства (Касаткин, 2011; Eastern Christianity and Politics..., 2014; Кырлежев, 2016). По мнению РПЦ, Константинополь уже давно является «выразителем греческих узконациональных, а не вселенских православных интересов» (Петрунина и др., 2020, c. 72). В свою очередь, Константинополь исторически является лидером православных церквей греческого обряда, к коим принадлежит и АПЦ, чью паству составляют греки, проживающие в Египте. Именно принадлежность РПЦ и АПЦ к разным «блокам» внутри мирового православия является главным и пока неустранимым препятствием на пути установления более прочных и регулярных контактов между двумя церквами.

\section{РПЦ - Коптская церковь}

Копты составляют самую многочисленную христианскую общину на Ближнем Востоке и в Северной Африке. Диалог между РПЦ и КПЦ в Новейшее время начал активно развиваться во второй половине прошлого века: предстоятели Московского патриархата посещали Египет в 1945, 1960, 1991 и 2010 гг. В свою очередь, патриархи Коптской церкви посещали Москву в 1972, 1988, а затем в 2014 г. (Аджбан, 2015). Кроме того, в России находится представитель Коптской церкви, которым в настоящее время является иеромонах Дауд аль-Антони.

Ключевым направлением взаимодействия РПЦ и КПЦ является преодоление многовековых разногласий по богословским вопросам, которые долгие столетия создавали в отношениях двух церквей атмосферу взаимного недоверия. Первый раунд переговоров по

${ }^{29}$ Александрийская Православная Церковь (историческая справка) // РПЦ. URL: http://www.patriarchia.ru/ db/text/134420.html (дата обращения: 02.09.2021). 
данной проблеме состоялся в январе 2020 г. в Нидерландах. Кроме того, в рамках активной деятельности РПЦ по привлечению внимания мировой общественности к проблеме гонений на ближневосточных христиан Московский патриархат неоднократно выражал обеспокоенность положением египетских коптов, особенно в ходе событий «арабской весны» и после прихода к власти движения «Братьямусульмане ${ }^{30}$.

В 2014 г. была создана двусторонняя Комиссия по диалогу между Русской православной и Коптской церквами, первое заседание которой состоялось в феврале 2016 г. в Каи$\mathrm{pe}^{31}$. Самыми значимыми сферами сотрудничества двух церквей объявлены двусторонние богословские консультации, а также взаимодействие в академической, медийной, соииальной и молодежной сферах ${ }^{32}$. Данные сферы выбраны неслучайно: обе церкви уделяют значительное внимание работе с молодым поколением верующих, поскольку в России все меньше молодых людей стремятся приобщиться к вере, а в Египте в условиях социальной и политической нестабильности среди молодежи растут радикальные настроения.

23 мая 2017 г. в Москве состоялась встреча Святейшего Патриарха Московского и всея Руси Кирилла со Святейшим Патриархом Коптским Тавадросом II, в ходе которой РПЦ отметила свою удовлетворенность «разумной политикой правительства Египта в отношении межрелигиозных связей» ${ }^{33}$, несмотря на случаи нападения на коптские святыни в Египте. Визиту Тавадроса II предшествовало посещение Москвы 11-17 марта делегацией Коптской церкви с целью

30 Организация запрещена в РФ.

${ }^{31}$ Состоялась встреча Святейшего Патриарха Кирилла с Патриархом Коптской Церкви // РПЦ. 23.05.2017. URL: http://www.patriarchia.ru/db/text/ 4903265.html (дата обращения: 20.09.2021).

32 В Россию прибыла делегация игуменов и насельников египетских монастырей // РПЦ. 24.08.2021. URL: http://www.patriarchia.ru/db/text/5838002.html (дата обращения: 20.09.2021).

${ }^{33}$ Состоялась встреча Святейшего Патриарха Кирилла с Патриархом Коптской Церкви // РПЦ. 23.05.2017. URL: http://www.patriarchia.ru/db/text/ 4903265.html (дата обращения: 20.09.2021). ознакомления с социальным служением Московского патриархата в рамках деятельности двусторонней Комиссии ${ }^{34}$.

В рамках двустороннего сотрудничества РПЦ и КПЦ также наладили обмены студентами и монашескими группами, а также контакты на уровне библиотек, регентских и иконописных школ ${ }^{35}$. Российская сторона предоставляет стипендии египетским коптам, обучающимся в духовных семинариях и светских высших учебных заведениях России ${ }^{36}$.

Таким образом, диалог между РПЦ и КПЦ, несмотря на отсутствие евхаристического общения, развивается более активно, чем взаимодействие Московского и Александрийского патриархатов. Как представляется, это обусловлено невовлеченностью Коптской церкви в противостояние между Москвой и Константинополем (КПЦ не поддержала раскольнические настроения внутри Православной церкви Украины), а также заинтересованностью обеих сторон в укреплении связей. Для России КПЦ является единственным реальным союзником в Египте, а для КПЦ важна поддержка РПЦ в деле отстаивания интересов коптской общины и повышения ее роли в общественно-политической жизни в мусульманском государстве.

В то же время необходимо отметить, что в 2019 г., по сообщениям СМИ, которые не нашли подтверждения на официальном сайте Московского патриархата, глава Коптской церкви Тавадрос II признал автокефалию Православной церкви Украины. В ответ на это РПЦ якобы разорвала отношения с лидером египетских коптов, при этом сохранив связи с другими высокопоставленными священниками, поскольку Священный Синод

\footnotetext{
${ }^{34}$ Там же.

${ }^{35}$ Состоялось совещание по вопросу развития сотрудничества духовных школ Русской Православной Церкви и Коптской Церкви // Отдел внешних церковных связей Московского патриархата. 29.08.2021. URL: https://mospat.ru/ru/news/87942/ (дата обращения:

${ }^{36}$ Глава Нижегородской митрополии встретился со студентами - представителями коптской общины // Отдел внешних церковных связей Московского Патриархата. URL: https://mospat.ru/ru/news/88294/ (дата обращения: 20.09.2021).
} 20.09.2021). 
Египта не имел отношения к решению патриарха Тавадроса $\mathrm{II}^{37}$. Ситуация остается до конца не проясненной, поскольку других источников информации по указанному поводу найти не удалось. Кроме того, последующие частые контакты представителей двух церквей и отсутствие официальных заявлений с обеих сторон противоречат сообщениям о разрыве отношений. Подобная сомнительная информация не отразится на наших выводах, хотя и вынудит нас продолжить изыскания по поводу позиции КПЦ относительно статуса Православной церкви Украины.

\section{Нет институтов - нет диалога: мусульмане-шииты}

В контексте шиитской истории Египет занимает особое место, поскольку именно на его территории в 909-1171 гг. существовал Фатимидский халифат шиитов-исмаилитов. Кроме того, один из самых авторитетных в мире исламских высших учебных заведений - Университет Аль-Азхар, базирующийся в Каире, изначально был одним из центров исмаилитской общественно-политической мысли и образования. В Каире также находится мечеть Сайидуна аль-Хусейн, одна из старейших в Египте. Мечеть названа в честь ключевой фигуры шиитского ислама - имама Хусейна ибн Али. По одной из версий (правда, не имеющей достоверных доказательств), в 1153 г. голова Хусейна была перенесена из иракского города Кербела, где захоронен имам, в Египет, и для хранения этой ценности в 1154 г. была и воздвигнута мечеть Сайидуна аль-Хусейн.

Точная численность шиитского населения Египта неизвестна. Как представляется, это может быть связано с традицией соблюдения принципа ат-такыйя - сокрытия религиозных убеждений с целью выживания себя и единоверцев, который приобретает особую актуальность в условиях социальной дискриминации (страха перед потерей работы

${ }^{37}$ Russian Church Cuts Ties with Egypt's Coptic Pope over Ukraine // Naharnet. December 26, 2019. URL: https://www.naharnet.com/stories/en/267595 (accessed: 01.10.2021). или карьерных перспектив) и межконфессиональных столкновений. Здесь будет уместна параллель с другим североафриканским государством - Королевством Марокко, страной с незначительным (но в последние годы динамично растущим) шиитским меньшинством, где следование принципу ат-такыйя также не позволяет оценить численность шиитского сообщества (Чикризова, Морозова, 2020, c. 29).

Согласно египетскому законодательству, переход человека из одной религии в другую разрешается, однако на практике правительство признает только обращение в ислам представителей других религий, в то время как переход из ислама, например, в христианство сопровождается огромным количеством бюрократических процедур, серьезно осложняющих жизнь такому «вышедшему» из ислама гражданину ${ }^{38}$. В свою очередь, обращение суннитов в шиизм нельзя рассматривать как переход в другую религию, это внутриисламское «перемещение», которое, по сути, не должно было повлечь за собой каких-либо юридических последствий. Однако на практике все несколько иначе.

По мнению К. Асето, обращение в шиизм в случае египетских мусульман-шиитов нередко выступало как форма личностной эмансипации, особенно это касается первого поколения «обращенных» на волне эйфории от успехов Исламской революции в Иране (Aceto, 2017, p. 5). С политической точки зрения большинство египетских шиитов составляют противники концепции «велаят-э факих» аятоллы Хомейни, лидера иранской Исламской революции. Они выступают за сохранение светского характера египетского государства (Aceto, 2017, p. 1).

Сложившаяся в Египте система межконфессиональных отношений очень сильно напоминает систему миллетов (автономных религиозных общин), существовавшую в Османской империи: в этом исламском государстве, где мусульмане были господствующей общностью (миллет-и хакиме), были

\footnotetext{
${ }^{38}$ Egypt 2020 International Religious Freedom Report. United States Department of State, 2020. P. 4.
} 
созданы руководимые, «подчиненные» общины (миллет-и махкюме) - православная (Рум миллети), армянская (Эрмени миллети) и иудейская (Яхуда миллети), каждой из которых разрешалось сохранять свою веру, соблюдать обряды и иметь судебную автономию по таким вопросам, как браки и разводы, наследование, некоторые уголовные дела, использование церковного имущества и т. д. Мусульманские судьи (кади) рассматривали только те споры с участием немусульманина, где ему противостоял мусульманин (Орешкова, 2018, с. $420-421,482$ ).

В рамках данной системы мусульманешииты, в отличие от суннитов, христиан и иудеев, не признаны правительством как религиозное сообщество, имеющее право открыто отправлять свои религиозные обряды и строить культовые сооружения ${ }^{39}$. Также существуют свидетельства, что шииты в Египте не допускаются до службы в вооруженных силах, органах безопасности и разведке ${ }^{40}$. В этой связи, с одной стороны, можно назвать египетских шиитов дискриминируемым меньшинством. С другой стороны, шиитские браки признаются мусульманскими $^{41}$, что свидетельствует о том, что шииты не исключаются полностью из мусульманского сообщества Египта, по крайней мере в правовом аспекте.

Вместе с тем нередки случаи судебного преследования мусульман-шиитов в Египте именно за их религиозные убеждения, которые часто смешиваются с политикой. Так, основанием для обвинений в адрес известного шиитского активиста Ахмеда Расема анНафиса стала опасность, якобы проистекающая из шиитской идеологии, для египетского общества и национальной безопасности, поскольку, по мнению египетского правосудия, шииты в Египте используют религию в

39 Данный запрет также распространяется на бахаитов, членов Церкви Иисуса Христа и Свидетелей Иеговы.

${ }^{40}$ Egypt 2020 International Religious Freedom Report. United States Department of State, 2020. P. 14. URL: https://www.justice.gov/eoir/page/file/1395811/download (accessed: 18.08.2021)

${ }^{41}$ Ibid. P. 8. политических целях ${ }^{42}$. В то же время данные обвинения вступают в противоречие с фетвой экс-ректора Аль-Азхара Махмуда Шальтута, который в рамках деятельности «Джамаат аттакриб» в 1959 г. подтвердил легитимность шиитского джафаритского мазхаба наряду с четырьмя суннитскими правовыми школами - ханафитской, маликитской, шафиитской и ханбалитской (Чикризова, 2018, c. 170). Также в Египте, где запрещена деятельность политических партий, созданных на религиозной основе, провалилась попытка создать партию мусульман-шиитов, которая могла бы стать фактически единственным институтом, представляющим их интересы в условиях отсутствия шиитских религиозных организаций.

Что касается шиитской общины в России, то она представлена главным образом этническими азербайджанцами, хотя некоторая их доля привержена суннитскому исламу. Шиизм также исповедует значительная часть жителей Дагестана. При этом важно, что в Российской Федерации, как и в Египте, отсутствует единый институт, представляющий интересы разрозненных шиитских общин. Создано несколько организаций локального уровня, которые взаимодействуют между собой на низовом уровне ${ }^{43}$. Кроме того, в России отсутствует духовный лидер всех шиитов, который исполнял бы функции марджи aт-таклида (образца для подражания) и выступал непререкаемым авторитетом для всей общины.

Таким образом, нельзя говорить о какомлибо взаимодействии шиитов двух стран. При этом примечательно, что у РПЦ налажены устойчивые связи с шиитским Ираном, в том числе по линии диалога «Православие ислам», начатого в годы президентства М. Хатами (1997-2005 г.), который продвигал инициативу «Диалога цивилизаций». Однако в Иране шиизм является государственной

42 Ibid. P. 12.

43 Раис Сулейманов: «Шиизм в России постепенно институционализируется» // EurAsia Daily. 10.01.2021. URL: https:/eadaily.com/ru/news/2021/01/10/rais-suleymanovshiizm-v-rossii-postepenno-institucionaliziruetsya (дата обращения: 01.08.2021). См. также: (Гибадуллин, 2013). 
религией и представлен многочисленными институтами, в отличие от шиизма в Египте. В этой связи в случае с Ираном сотрудничество осуществляется по первой модели двух институтов доминирующей религии.

\section{Заключение}

Анализ государственно-церковных отношений в России и Египте выявил существенные различия в подходах стран к доминирующему вероисповеданию и религиозным меньшинствам. Наиболее ярко эти различия проявляются в Египте, где только суннитский ислам получает финансовую поддержку со стороны правительства, а также играет весомую роль в общественно-политической жизни страны. Особый статус Университета АльАзхар и его великого шейха закреплены в Конституции Арабской Республики Египет.

Изучение общественно-политического положения христианских и мусульманских меньшинств Египта показало, что политические преобразования в стране, имевшие место за последние 10 лет, практически не изменили жизнь египетских христиан или мусульман-шиитов. По-прежнему имеют место факты ограничения прав коптов в таких сферах, как прием на государственную гражданскую и военную службу.

В свою очередь, в России по законодательству религиозные организации отделены от государства и имеют одинаковый статус, хотя уровень сотрудничества российского правительства с Русской православной церковью в части, касающейся отстаивания интересов РФ на международной арене посредством взаимодействия религиозных институтов, очевидно на порядок выше, чем с институтами, представляющими остальные общины верующих. В этой связи при иллюстрации особенностей четырех моделей взаимодействия религиозных институтов выделяется роль Московского патриархата, который развивает контакты не только с единоверцами, но и с инославными христианами, а также мусульманами, проживающими как в России, так и за рубежом.

Исходя из выделенных особенностей государственно-церковных отношений в
Египте, а также наличия острой проблемы религиофобии, стоящей перед всеми религиозными организациями, можно дать ряд практических рекомендаций для российской стороны, которая стремится сохранить и упрочить влияние на Ближнем Востоке.

Во-первых, целесообразно использовать слабые места политики египетского правительства по отношению к религиозным меньшинствам, в частности недостаточное финансирование деятельности, например, Коптской церкви. В свою очередь, для России оказание материальной помощи ближневосточным христианам - традиционный инструмент влияния в регионе. Наиболее перспективным партнером может стать Коптская православная церковь, поскольку у Александрийского патриархата уже есть покровители в лице греческого правительства и Константинопольской православной церкви. При этом в современных условиях материальная помощь может не ограничиваться банальным направлением финансовых средств, судьбу которых впоследствии сложно отследить. Более продуктивным здесь может оказаться продолжение практики предоставления квот и стипендий на обучение в российских духовных семинариях и академиях, тем более что подобная работа уже ведется, а также содействие со стороны государства работе двусторонней Комиссии РПЦ и КПЦ и многоплановая поддержка инициатив двух церквей.

Во-вторых, будет естественным использовать многосторонние каналы взаимодействия с египетскими мусульманами, в частности Университетом Аль-Азхар. Речь идет в первую очередь о трехстороннем формате диалога РПЦ - Ватикан - Аль-Азхар, поскольку для подобного диалога созданы все условия. В 2016 г. состоялась историческая встреча Патриарха Московского и всея Руси Кирилла с папой Римским Франциском, которая вывела межхристианский диалог из состояния «анабиоза», в 2017 г. было налажено взаимодействие РПЦ с Аль-Азхаром, а в 2019 г. возобновились контакты Аль-Азхара с Ватиканом. Этому в значительной степени способствовал личностный фактор: патриарх 
Кирилл долгие годы возглавлял ОВЦС РПЦ, и внешняя деятельность - один из его приоритетов; папа Франциск также провозгласил сближение религий важнейшей задачей своего папства. Свидетельством прорыва в отношениях двух христианских церквей стало заявление Совета ООН по правам человека о положении ближневосточных христиан, ставшее результатом совместной инициативы Ливана, Ватикана и России во взаимодействии с РПЦ. Очевидно, что поддержка российскими властями внешней деятельности Московского патриархата способствует продвижению межхристианского и межрелигиозного диалога, и подобная практика обязана получить продолжение на конференции, намеченной на 2022 г.

Перспективным трехсторонним форматом также может стать диалог РПЦ, Совета муфтиев России и Университета Аль-Азхар, для чего заложены достаточно прочные основы в виде соглашений между Советом муфтиев и египетским университетом, а российские религиозные институты взаимодействуют в рамках деятельности органов власти и на многочисленных международных площадках межрелигиозного сотрудничества.

Наконец, в диалоге с Аль-Азхаром у РПЦ существует важное преимущество перед Ватиканом: Московский патриархат, являющийся религиозной организацией, представляющей интересы доминирующей религии России, близок по статусу к Аль-Азхару, и их двусторонние отношения лишены той асимметрии, которая присутствует в контактах государства Ватикан с Университетом АльАзхар. Финансовые и дипломатические возможности Святого престола, которые ограничиваются только количеством католиков в отдельно взятой стране, могут вызывать обеспокоенность у руководства египетского университета (Pratt, 2010; 2015). В свою очередь, РПЦ не имеет базы для прозелитизма на территории Египта, что делает ее безопасным партнером для Аль-Азхара, и России следует этим воспользоваться.

Поступила в редакцию / Received: 21.09.2021

Принята к публикации / Accepted: 26.10.2021

\section{Библиографический список}

Аджбан И.И. Отношения между двумя Церквами - Коптской и Русской - в XIX - XXI веках. Каир: Российские новости, 2015.

Беляков B.B. Роль гуманитарных связей в межкультурном взаимодействии России и Египта (конец ХIX середина XX века): дис. ... д-ра ист. наук. М., 2007.

Беляков B.B. Россия и Египет: межкультурное взаимодействие до Хрущева и Hacepa // Vitaleus: сборник статей, посвященный 70-летию В. И. Шеремета / отв. ред. В.В. Беляков, В.В. Наумкин. М.: Институт востоковедения РАН, 2010. С. 52-64.

Гибадуллин И.Р. Шиизм в России: поиск адекватной модели самоутверждения в общем контексте российской уммы // Ислам в мультикультурном мире: мусульманские движения и механизмы воспроизводства идеологии ислама в современном информационном пространстве: сборник статей международной конференции. Казань, 14-17 ноября 2013 г. / отв. ред. Д.В. Брилев. Казань: Казанский (Приволжский) федеральный университет, 2013. С. 67-88.

Горячкин Г.В. Русское присутствие в Палестине как фактор взаимоотношений между правящими династиями России и Египта (конец XIX — начало XX в.) // Православный палестинский сборник. 2014. Вып. 110. С. $72-78$.

Данненберг А.Н., Касаткин П.И. Святой престол на Святой земле: история и современность // Вестник МГИМО Университета. 2018. № 2 (59). С. 185-200. DOI: 10.24833/2071-8160-2018-2-59-185-200

Егорин А.3. Египет - Россия: 500 лет сотрудничества. Казань: Изд-во Казанского университета, 2016.

Егорин А.3. Египет нашего времени. М.: ИВ РАН, 1998.

Касаткин П.И. Управление церковной диаспорой как ключевая проблема межправославных отношений // Право и управление. XXI век. 2011. № 4 (21). С. $72-79$.

Керимов Г.М. Проблемы войны и мира в исламе // Вопросы научного атеизма. Вып. 31: Современный ислам и проблемы атеистического воспитания. М.: Мысль, 1983. С. 148-162. 
Кириллина С.А. Русские путешественники и миссионерские деятели в Египте XIX - начала XX в. и их взгляды на культурный подъем на Арабском Востоке // Россия и Восток: взгляд из Сибири в конце столетия: материалы и тезисы докладов к международной научно-практической конференции. Иркутск, 24-27 мая 2000 года: в 2 т. Т. 1. Иркутск: Оттиск, 2000. С. 250-255.

Кырлежев А. Мировое православие: типология автокефальных церквей // Государство, религия, Церковь в России и за рубежом. 2016. Т. 34. № 1. С. 74-101. DOI: 10.22394/2073-7203-2016-34-1-74-101

Орешкова С.Ф. Османская империя: очерки истории. М.: Издательский дом «Рубежи XXI», 2018.

Петрунина О.Е., Герд Л.А., Вах К.А. Александрийский патриархат и Россия в XIX веке: исследования и документы. М.: Индрик, 2020.

Халиль М.А.М. Межкультурная коммуникация России и Египта в XX-XXI вв.: политические и религиозные аспекты. М.: МГИМО-Университет, 2019.

Чикризова О.С. «Экуменизм» в исламе: исторические этапы преодоления суннито-шиитского антагонизма // Экономические, социально-политические, этноконфессиональные проблемы афро-азиатских стран. Ежегодник 2018. С. 166-172.

Чикризова О.С., Морозова Н.Н. Шиизм в Марокко: историческое наследие и современность // Азия и Африка сегодня. 2020. № 5. С. 28-35. DOI: 10.31857/S032150750009547-3

Шахов М.О. Правовые основы деятельности религиозных объединений в Российской Федерации: 2-е изд., доп. М.: Изд-во Сретенского монастыря, 2013.

Aceto C. Shi'a in Egypt. One in a Hundred: Analysis of Sectarianism - Confronting a Controversial and Fragmented Community. Aahrus University, 2017. URL: https://www.academia.edu/32601963/Shi_a_ in_Egypt_One_in_a_Hundred_Analysis_of_Sectarianism_Confronting_a_Controversial_and_Fragmented_ Community (accessed: 12.08.2021).

Eastern Christianity and Politics in the Twenty-First Century / ed. by L.N. Leustean. London-New York: Routledge, 2014.

El Masri I.H. The Story of the Copts: The True Story of Christianity in Egypt. Book I: From the Foundation of the Church by Saint Mark to the Arab Conquest. Cairo: Middle East Council of Churches, 1978.

Fahmi G. The Rapprochement between Al-Azhar and the Vatican: Opportunities and Limits // Cooperation with Religious Institutions as a European Policy Tool / ed. by P. Sasnal. European Institute of the Mediterranean, 2019. P. 98-116.

Fox J. A World Survey of Secular-Religious Competition: State Religious Policy from 1990 to 2014 // Religion, State \& Society. 2019. Vol. 47. No. 1. P. 10-29. DOI: 10.1080/09637494.2018.1532750

Fox J. Political Secularism, Religion, and the State: A Time Series Analysis of Worldwide Data. New York, NY: Cambridge University Press, 2015.

Grim B.J., Finke R. International Religion Indexes: Government Regulation, Government Favoritism, and Social Regulation of Religion // Interdisciplinary Journal of Research on Religion. 2006. Vol. 2. P. $1-40$.

Hall P.A., Taylor R.C.R. Political Science and the Three New Institutionalisms // Political Studies. 1996. Vol. 44. No. 5. P. 936-957. DOI: 10.1111/j.1467-9248.1996.tb00343.x

Hurd E.S. Beyond Religious Freedom: The New Global Politics of Religion. Princeton, NJ: Princeton University Press, 2017.

Martino M.G. The State as an Actor in Religion Policy: Policy Cycle and Governance Perspectives on Institutionalized Religion. Wiesbaden: Springer, 2014.

Peters B.G. Institutional Theory: Problems and Prospects // Reihe Politikwissenschaft. 2000. Vol. 69. P. 1-28. URL: https://www.ihs.ac.at/publications/pol/pw_69.pdf (accessed: 20.07.2021).

Pratt $D$. The Vatican in Dialogue with Islam: Inclusion and Engagement // Islam and Christian-Muslim Relations. 2010. Vol. 21. No. 3. P. 245-262. DOI: 10.1080/09596410.2010.496656

Pratt D. Theology after Dialogue: Christian-Muslim Engagement Today and Tomorrow // Islam and ChristianMuslim Relations. 2015. Vol. 26. No. 1. P. 89-101. DOI: 10.1080/09596410.2014.965882

\section{References}

Aceto, C. (2017). Shi'a in Egypt. One in a hundred: Analysis of sectarianism - confronting a controversial and fragmented community. Aahrus University. Retrieved from https://www.academia.edu/32601963/ Shi_a_in_Egypt_One_in_a_Hundred_Analysis_of_Sectarianism_Confronting_a_Controversial_and_Fragment ed_Community

Adjban, I. I. (2015). Relations between the two Churches - Coptic and Russian - in the 19th - 21st centuries. Cairo: Rossijskie novosti publ. (In Russian). 
Belyakov, V. V. (2007). The role of humanitarian ties in intercultural interaction between Russia and Egypt (late 19th - mid 20th centuries) [thesis]. Moscow. (In Russian).

Belyakov, V. V. (2010). Russia and Egypt: Intercultural interaction before Khrushchev and Nasser. In V. V. Belyakov \& V. V. Naumkin (Eds.), Vitaleus: a collection of articles dedicated to the 70th anniversary of V. I. Sheremet (pp. 52-64). Moscow: Institut vostokovedeniya RAN publ. (In Russian).

Chikrizova, O. S. (2018). "Ecumenism" in Islam: Historical stages of overcoming the Sunni-Shi'ite antagonism. Economic, Socio-Political, Ethno-Confessional Problems of Afro-Asian Countries. Yearbook, 166-172. (In Russian).

Chikrizova, O. S., \& Morozova, N. N. (2020). Shi'ism in Morocco: Historical heritage and modernity. Asia and Africa Today, (5), 28-35. (In Russian). https://doi.org/10.31857/S032150750009547-3

Dannenberg, A. N., \& Kasatkin, P. I. (2018). The Holy See in the Holy land: History and the present. MGIMO Review of International Relations, (2), 185-200. (In Russian). https://doi.org/10.24833/2071-8160-2018-2-59$185-200$

Egorin, A. Z. (1998). Egypt of our times. Moscow: IV RAN publ. (In Russian).

Egorin, A. Z. (2016). Egypt - Russia: 500 years of cooperation. Kazan: Izd-vo Kazanskogo universiteta publ. (In Russian).

El Masri, I. H. (1978). The story of the Copts: The true story of Christianity in Egypt. Book I: From the foundation of the Church by Saint Mark to the Arab conquest. Cairo: Middle East Council of Churches.

Fahmi, G. (2019). The Rapprochement between Al-Azhar and the Vatican: Opportunities and Limits. In P. Sasnal (Ed.), Cooperation with religious institutions as a European policy tool (pp. 98-116). European Institute of the Mediterranean.

Fox, J. (2015). Political secularism, religion, and the state: A time series analysis of worldwide data. New York, NY: Cambridge University Press.

Fox, J. (2019). A world survey of secular-religious competition: state religious policy from 1990 to 2014. Religion, State \& Society, 47(1), 10-29. https://doi.org/10.1080/09637494.2018.1532750

Grim, B. J., \& Finke, R. (2006). International religion indexes: Government regulation, government favoritism, and social regulation of religion. Interdisciplinary Journal of Research on Religion, 2, 1-40.

Gibadullin, I. R. (2013). Shi'ism in Russia: The search of appropriate model of self-constitution within Russian Muslim community. In D. V. Brilev (Ed.), Islam in a multicultural world: Muslim movements and mechanisms of the reproduction of the ideology of Islam in the modern information space: a collection of articles of the international conference (pp. 67-88). Kazan, November 14-17, 2013. Kazan: Kazanskii (Privolzhskii) federal'nyi universitet publ. (In Russian).

Goryachkin, G. V. (2014). Russian presence in Palestine as a factor in the relationship between the ruling dynasties of Russia and Egypt (late 19th - early 20th centuries). Orthodox Palestinian Collection, (110), 72 -78. (In Russian).

Hall, P. A., \& Taylor, R. C. R. (1996). Political science and the three new institutionalisms. Political Studies, 44(5), 936-957. https://doi.org/10.1111/j.1467-9248.1996.tb00343.x

Hurd, E. S. (2017). Beyond religious freedom: The new global politics of religion. Princeton, NJ: Princeton University Press.

Kasatkin, P. I. (2011). Governance of church diaspora as a key problem of inter-Orthodox relations. Journal of Law and Administration, (4), 72-79. (In Russian).

Kerimov, G. M. (1983). Problems of war and peace in Islam. Questions of Scientific Atheism, (31), 148-162. Moscow: Mysl' publ. (In Russian).

Khalil, M. A. M. (2019). Intercultural communication between Russia and Egypt in the 20th - 21st centuries: Political and religious aspects. Moscow: MGIMO-Universitet publ. (In Russian).

Kirillina, S. A. (2000). Russian travellers and missionary figures in Egypt in the 19th - early 20th centuries and their views on the cultural upsurge in the Arab East. In Russia and the East: a view from Siberia at the end of the century: materials and abstracts of reports for the international scientific-practical conference. Irkutsk, May 24-27, 2000: in 2 volumes. Vol. 1 (pp. 250-255). Irkutsk: Ottisk publ.

Kyrlezhev, A. (2016). Orthodox commonwealth: A typology of autocephalous churches. State, Religion and Church in Russia and Worldwide, 34(1), 74-101. (In Russian). https://doi.org/10.22394/2073-7203-2016-34-1-74-101

Leustean, L. N. (Ed.) (2014). Eastern Christianity and politics in the twenty-first century. London - New York: Routledge.

Martino, M. G. (2014). The State as an actor in religion policy: Policy cycle and governance perspectives on institutionalized religion. Wiesbaden: Springer.

Oreshkova, S. F. (2018). The Ottoman Empire: Essays on history. Moscow: Rubezhi XXI publ. (In Russian). 
Peters, B. G. (2000). Institutional theory: Problems and prospects. Reihe Politikwissenschaft, 69, 1-28. Retrieved from https://www.ihs.ac.at/publications/pol/pw_69.pdf

Petrunina, O. E., Gerd, L. A., \& Vakh, K. A. (2020). The Alexandrian Patriarchate and Russia in the 19th century: Research and documents. Moscow: Indrik publ. (In Russian).

Pratt, D. (2010). The Vatican in dialogue with Islam: Inclusion and engagement. Islam and Christian-Muslim Relations, 21(3), 245-262. https://doi.org/10.1080/09596410.2010.496656

Pratt, D. (2015). Theology after dialogue: Christian-Muslim engagement today and tomorrow. Islam and ChristianMuslim Relations, 26(1), 89-101. https://doi.org/10.1080/09596410.2014.965882

Shakhov, M. O. (2013). Legal basis for the activities of religious associations in the Russian Federation. 2nd edition. Moscow: Izd-vo Sretenskogo monastyrya publ. (In Russian).

Сведения об авторах: Лукьянова Галина Олеговна - кандидат филологических наук, доцент, заведующая кафедрой иностранных языков факультета гуманитарных и социальных наук Российского университета дружбы народов; ORCID: 0000-0002-4033-4852; e-mail: lukianova-go@rudn.ru

Чикризова Ольга Сергеевна - кандидат исторических наук, доцент кафедры теории и истории международных отношений Российского университета дружбы народов; ORCID: 0000-0002-1678-0967; e-mail: chikrizova-os@rudn.ru

\footnotetext{
About the authors: Lukyanova Galina Olegovna - PhD in Philology, Associate Professor, Head, Department of Foreign Languages, Faculty of Humanities and Social Sciences, Peoples' Friendship University of Russia (RUDN University); ORCID: 0000-0002-4033-4852; e-mail: lukianova-go@rudn.ru

Chikrizova Olga Sergeevna - PhD in History, Associate Professor, Department of Theory and History of International Relations, Peoples' Friendship University of Russia (RUDN University); ORCID: 0000-0002-1678-0967; e-mail: chikrizova-os@rudn.ru
} 